\title{
LASIURINE BATS IN NOVA SCOTIA
}

\author{
ZOE LUCAS $^{1}$ and ANDREW HEBDA ${ }^{2}$ \\ ${ }^{I}$ PO Box 64, Halifax CRO, Halifax, Nova Scotia, Canada B3J 2L4 \\ zoelucas@greenhorsesociety.com \\ ${ }^{2}$ Nova Scotia Museum, 1747 Summer Street, \\ Halifax, Nova Scotia, Canada B3H 3 A6 \\ hebdaaj@gov.ns.ca
}

\begin{abstract}
Three lasiurine bat species, Lasionycteris noctivagans (Silver-haired Bat), Lasiurus cinereus (Hoary Bat), and Lasiurus borealis (Red Bat), have been recorded in inland, coastal, and offshore locations as of Nova Scotia. Although these records occurred over a century, $70 \%$ are from the mid-1990s or later, largely because of research in mainland Nova Scotia, and increased interest on Sable Island. The 65 records presented here include 11, 25, and 29 for Silver-haired, Hoary, and Red bats, respectively, of which 31 are previously unpublished. Seventy-seven percent of records are from August through November, the autumn migration period for lasiurine bats. These observations suggest that most autumn occurrences of these species in Nova Scotia are not extralimital, but are part of normal migratory patterns in the province.
\end{abstract}

\section{INTRODUCTION}

Seven vespertilionid species are recorded for Nova Scotia (Broders et al. 2003, Rockwell 2005, Scott \& Hebda 2004). The province is thought to be at or beyond the northern range limit for 5 of the 7 species, including the 3 species of North American lasiurine bats, Lasionycteris noctivagans (LeConte) Silver-haired Bat, Lasiurus cinereus (Palisot de Beauvois) Hoary Bat, and Lasiurus borealis (Müller) Red Bat (Broders et al. 2003, van Zyll de Jong 1985). In June-August 2003, during a province-wide survey, Rockwell (2005) recorded $>10,000$ identifiable echolocation sequences, of which only $0.4 \%$ were from lasiurine bats. Broders et al. (2003) suggest that the lack of detection of these species in mid-summer in the forested areas of Kejimkujik National Park and during September (migration period) at islands in southwestern Nova Scotia, demonstrates that there are no significant populations of lasiurine bats in Nova Scotia. They conclude that records for these species, including a Red Bat breeding record from Yarmouth County, are likely extralimital. Extensive monitoring programs continued since 2003 in mainland Nova Scotia during summer, and to a lesser extent 
in autumn, appears to support this conclusion. Of the thousands of echolocation records collected, very few lasiurine bats were recorded (pers. comm. H. Broders, 2011).

Lasiurine bats are highly migratory, some moving south hundreds of kilometres during autumn (Cryan 2003, van Zyll de Jong 1985). Silver-haired, Hoary, and Red bats are generally solitary, but during migration may form flocks of $>100$ individuals (Carter 1950, Miller 1897). Fenton (1983) notes that the rearing of young in midsummer is followed by mating season and migration, a period during which bats of temperate areas become vagrants; this can result in bats turning up in unexpected locations such as ships at sea and far offshore islands.

We first review prior distributional and migratory knowledge of lasiurine bats found in Nova Scotia in the context of their biology in North America. We then provide data on new records in Nova Scotia and discuss this in terms of the underlying ecology of the three species.

\section{Silver-haired Bat}

The Silver-haired Bat (mean weight $11 \mathrm{~g}$, wingspan 27-31 cm; van Zyll de Jong 1985) ranges from southeastern Alaska and much of Canada, with a maximum latitude of $61^{\circ} 07^{\prime} \mathrm{N}$ (Cryan 2003, Hall 1981), and extends south to northern Mexico (Cryan 2003). This species is relatively scarce in eastern Canada, but fairly common across central North America (Hall 1981, Peterson 1966). Over most of its range, both sexes fly south between middle of August and early October. Records along northern parts of the Atlantic Coast in autumn indicate that some Silver-haired Bats may migrate along coastlines (Cryan 2003). Banfield (1974) notes that Silver-haired Bats have "been observed migrating in flocks, far at sea, off the east coast of the United States, and have been blown as far as Bermuda in autumn storms". This species apparently has well-developed homing instinct (Nowak 1994). In the eastern USA they winter mainly at mid latitudes, approximately south of Michigan and east of the Mississippi River (Cryan 2003, van Zyll de Jong 1985). Van Zyll de Jong (1985) states that they have been captured flying at temperatures below freezing $\left(-2^{\circ} \mathrm{C}\right)$ and will hibernate north approximately to the $-6.7^{\circ} \mathrm{C}$ mean daily minimum January isotherm. Cryan (2003) notes occasional reports of Silver-haired Bats hibernating in caves, mines and trees. Previous winter records for Canada are known from southern Ontario, southwestern British Columbia, and mainland Nova Scotia (Moseley 2007a, Moseley 2007b, Peterson 1966, van Zyll 
de Jong 1985), and include 1 bat found clinging to a stone pillar on December 16, 1959, in Rondeau Provincial Park, Ontario.

\section{Hoary Bat}

The Hoary Bat (mean weight 27.6 g, wingspan 34-41 cm; van Zyll de Jong 1985) has the most extensive range of any New World bat, extending from Canada south to Chile and Argentina (Cryan 2003). It occurs throughout most of North America south of the tree line (Cryan 2003, van Zyll de Jong 1985). Monitoring with bat detectors has established that this species is widely distributed in Canada and is common in many areas, although the species is seldom sighted. Individuals have been recorded far beyond areas that are considered suitable habitat (van Zyll de Jong 1985), as far north as Bear Island, at the northwest end of Hudson Bay and more than 500 miles above the treeline (Hitchcock 1943). Records indicate coastward movement during late summer (Cryan 2003). Fall migration takes place from mid-August to October, and most are thought to winter in southern USA and Mexico. There are few records for November-February north of Georgia and South Carolina in the east (van Zyll de Jong 1985), however several records for Connecticut, New York, Indiana, and Michigan suggest that some may winter farther north (van Zyll de Jong 1985). This species migrates some of the longest distances of any bat (Tuttle 1995). Strays have been reported from Iceland and Bermuda (Allen 1939, Hayman 1959, van Gelder \& Wingate 1961), and some have landed on ships at sea. Hoary Bats are thought to be rare in Nova Scotia (Broders et al. 2003, Scott \& Hebda 2004). However, based on echolocation recordings collected in 2003, Rockwell (2005) suggests that they are more common in summer than direct observations indicate.

\section{Red Bat}

The Red Bat (mean weight $12.5 \mathrm{~g}$, wingspan $28-33 \mathrm{~cm}$; van Zyll de Jong 1985) occurs throughout much of eastern North America, generally east of the continental divide in southern Canada from the Maritimes to Saskatchewan, south to northeastern Mexico (Cryan 2003, Hall 1981 , van Zyll de Jong 1985). The northernmost record is at $57^{\circ} 15^{\prime} \mathrm{N}$ (Hall 1981). Fall migration begins in late August and September and continues into October. Movements during autumn are oriented east and south (Cryan 2003). The relatively high densities after June along the Atlantic Coast (north of New York City) may indicate coastal migration 
during autumn (Cryan 2003). They winter generally south of latitude $40^{\circ} \mathrm{N}$ (van Zyll de Jong 1985), throughout southeastern USA and into northeastern Mexico. Cryan (2003) notes that winter concentrations are highest in coastal Atlantic and Gulf of Mexico regions. Known to survive temperatures as low as $-5^{\circ} \mathrm{C}$, this species responds to subfreezing temperatures by increasing metabolism just enough to keep its body temperature above the critical lower limit (van Zyll de Jong 1985). They are strong flyers with propensity to wander, sometimes landing on ships at sea or oceanic islands, especially Bermuda (Findley \& Jones 1964, van Gelder \& Wingate 1961). Most oceanic records are from late August and September (van Zyll de Jong 1985). In Nova Scotia, Red Bats are rare but probably widespread, and a confirmed breeding there in 2001 was a first for Atlantic Canada (Broders et al. 2003). Three of the 4 previously published extralimital or extraseasonal records for Nova Scotia have been from vessels off the southwest coast of the province (Brown 1953, Norton 1930, Peterson 1970).

\section{METHODS}

We reviewed published records, fluid-preserved carcasses, skins, photographs, and reliable sight records (based on details provided and/ or known experience of the observer), and solicited information from birders. Although bats represented by sight records were not captured and examined, in Red Bats sex could be determined because of the marked colour difference between the males and females of this species. Locations of occurrences are categorized as inland, coastal, coastal island, Sable Island, and vessel. Sable Island $\left(44^{\circ} \mathrm{N}, 60^{\circ} \mathrm{W}\right)$, the most offshore of Nova Scotia's islands, is approximately $160 \mathrm{~km}$ southeast of Canso, Nova Scotia, the nearest landfall. The island is roughly 45 $\mathrm{km}$ in length with a maximum width of $1.5 \mathrm{~km}$, and surface area of 3200 ha, $30 \%$ of which is vegetated. However, except for a solitary $50 \mathrm{~cm}$ high Scots Pine Pinus sylvestris Linnaeus, the island is treeless (Catling et al. 1984) and does not offer suitable foraging and roosting habitat for lasiurine bats.

\section{RESULTS}

Review of documents and specimens resulted in 65 records (11 Silver-haired, 25 Hoary, and 29 Red bats) in Nova Scotia (Figs 1, 2, and 3, and Tables 1, 2, 3, and 4). Of these, 16 are represented by 


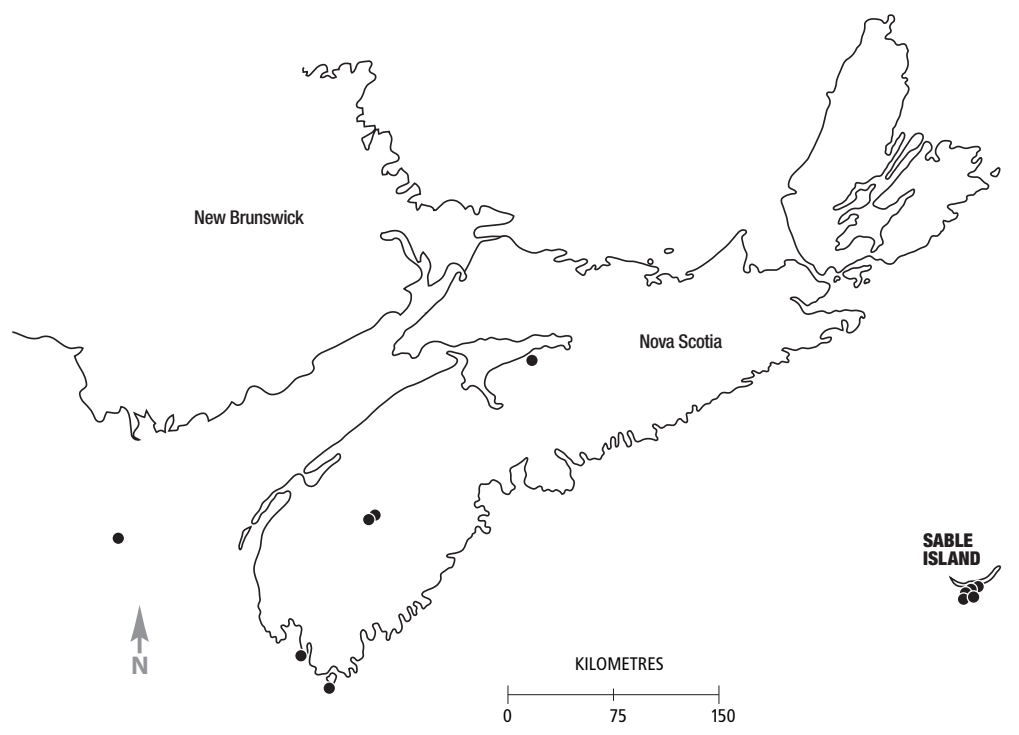

Fig 1 Silver-haired Bat records.

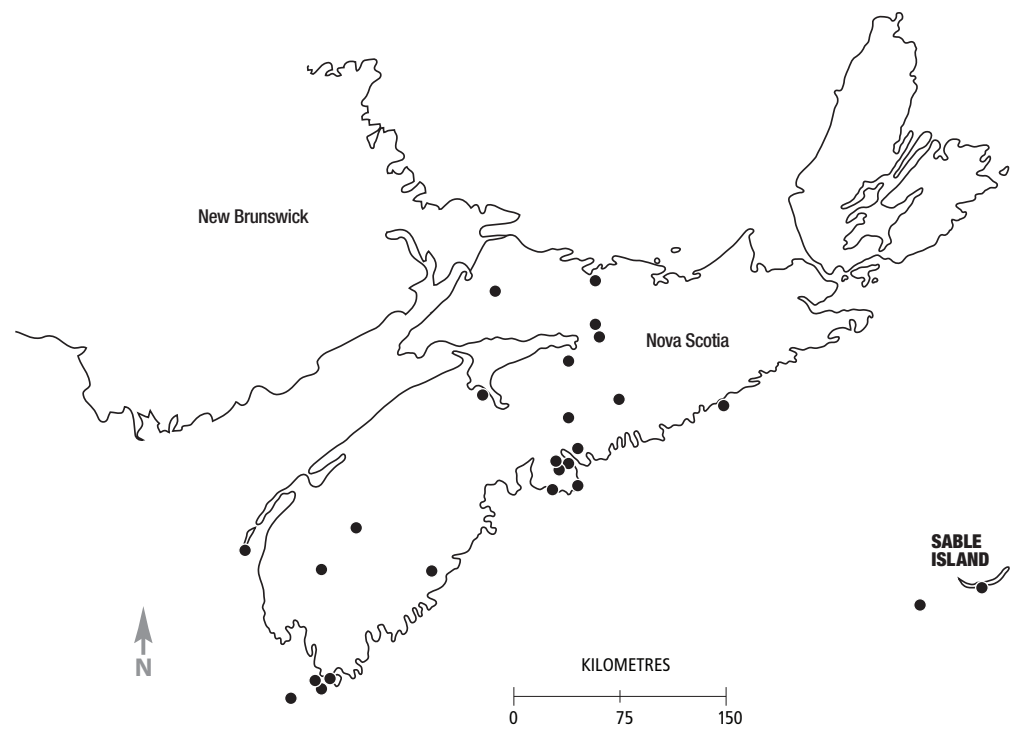

Fig 2 Hoary Bat records. 


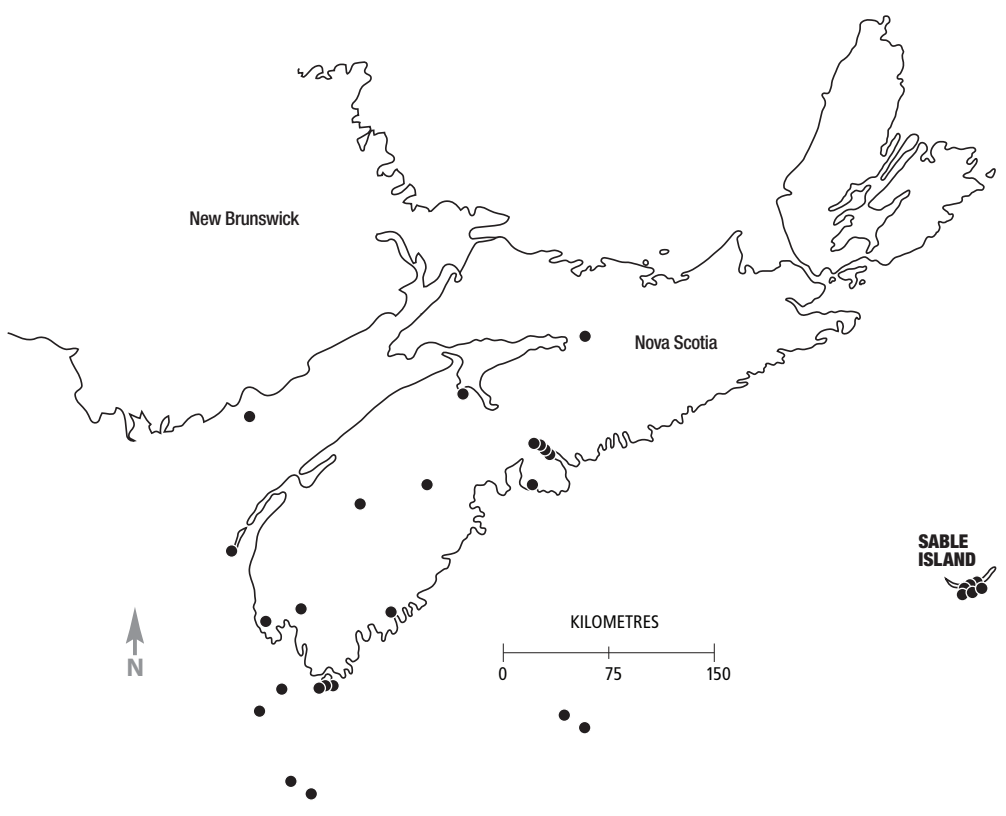

Fig 3 Red Bat records.

Table 1 Summary of records of tree bats in Nova Scotia

\begin{tabular}{lcrrr}
\hline & Silver-haired & Hoary & Red & Total \\
\hline Total records & 11 & 25 & 29 & 65 \\
Published & 2 & 20 & 12 & 34 \\
Unpublished & 9 & 5 & 17 & 31 \\
Record Type & & 7 & & \\
$\quad$ Specimen & 2 & 2 & 7 & 16 \\
$\quad$ Photo & 6 & 5 & 10 & 15 \\
$\quad$ Sight & 3 & & 4 & 18 \\
Echolocation & & $\mathbf{2 9}^{1}$ & $\mathbf{3 4}^{1}$ & 15 \\
$\quad$ Not recorded & & $\mathbf{1 2}$ & & $\mathbf{7 5}$ \\
Total individuals & & &
\end{tabular}

${ }^{1}$ Includes echolocation records as one bat each 


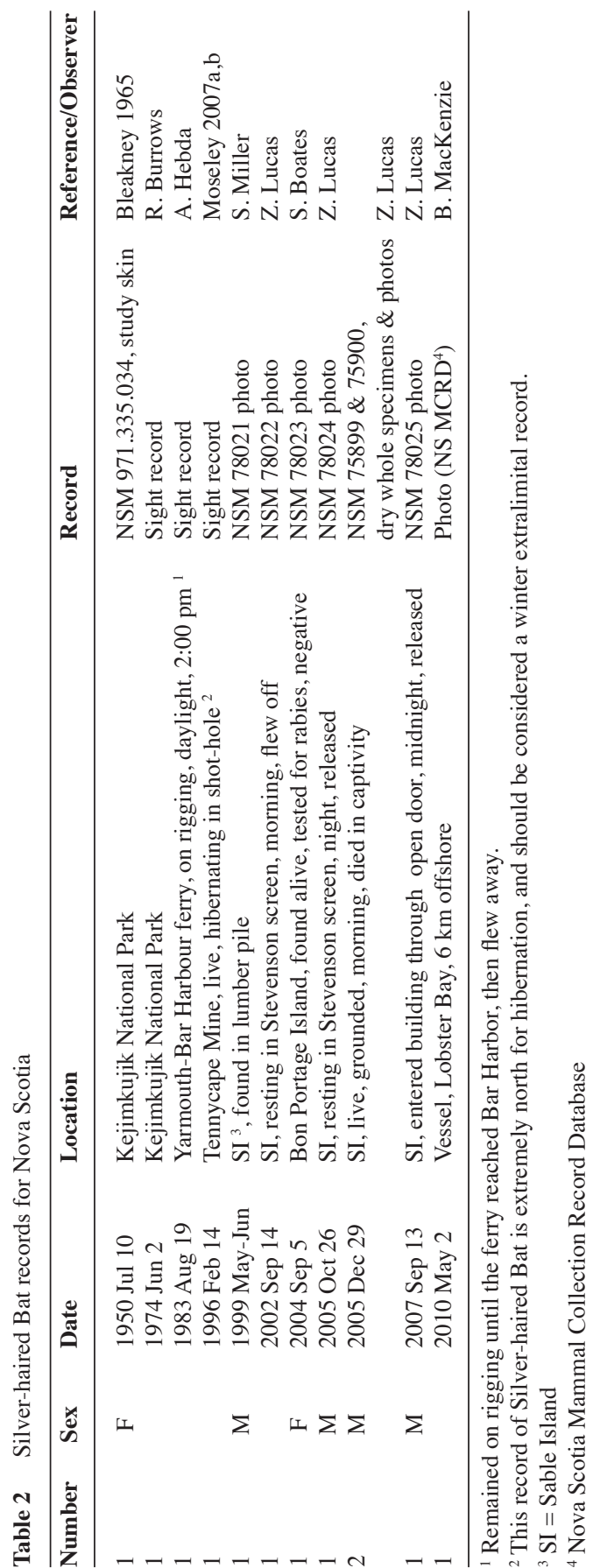




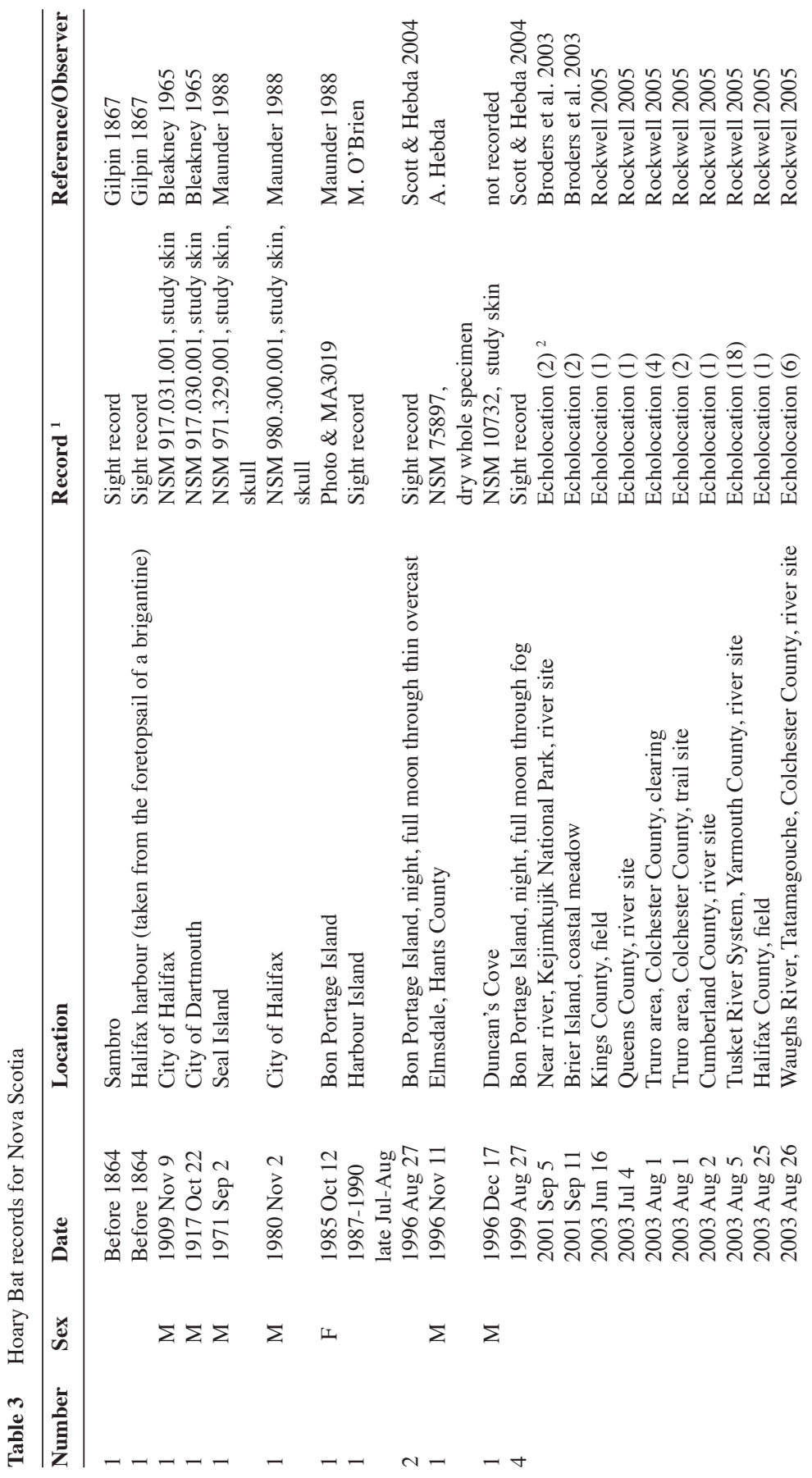




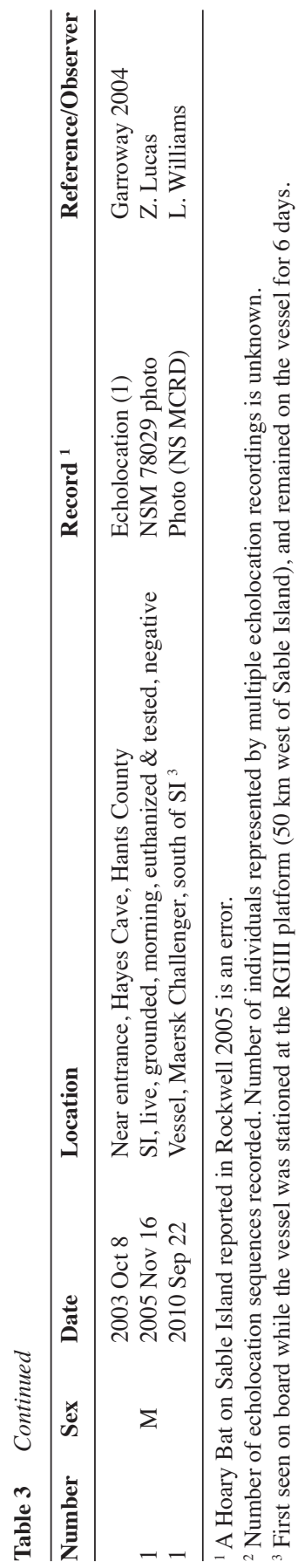




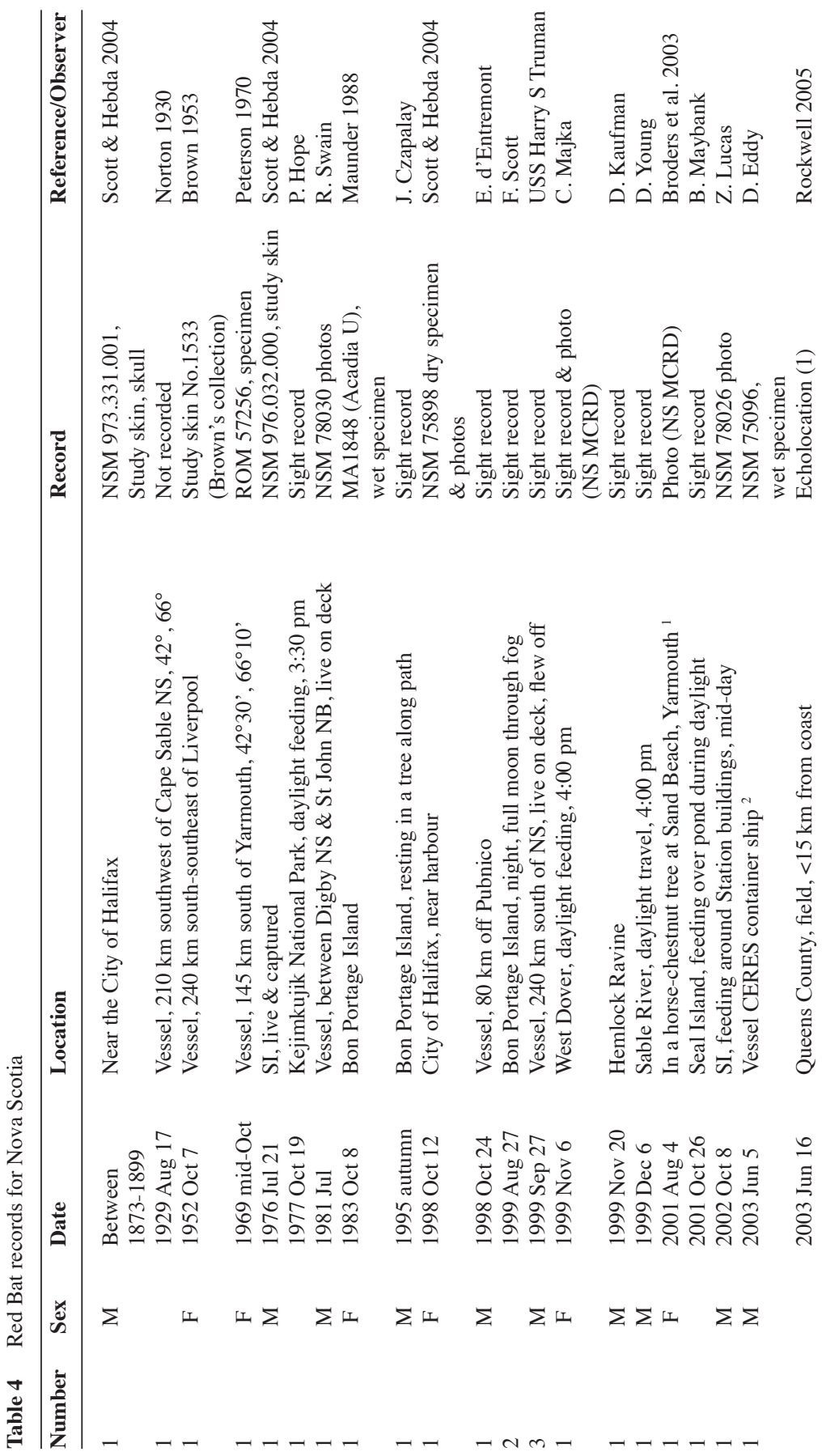




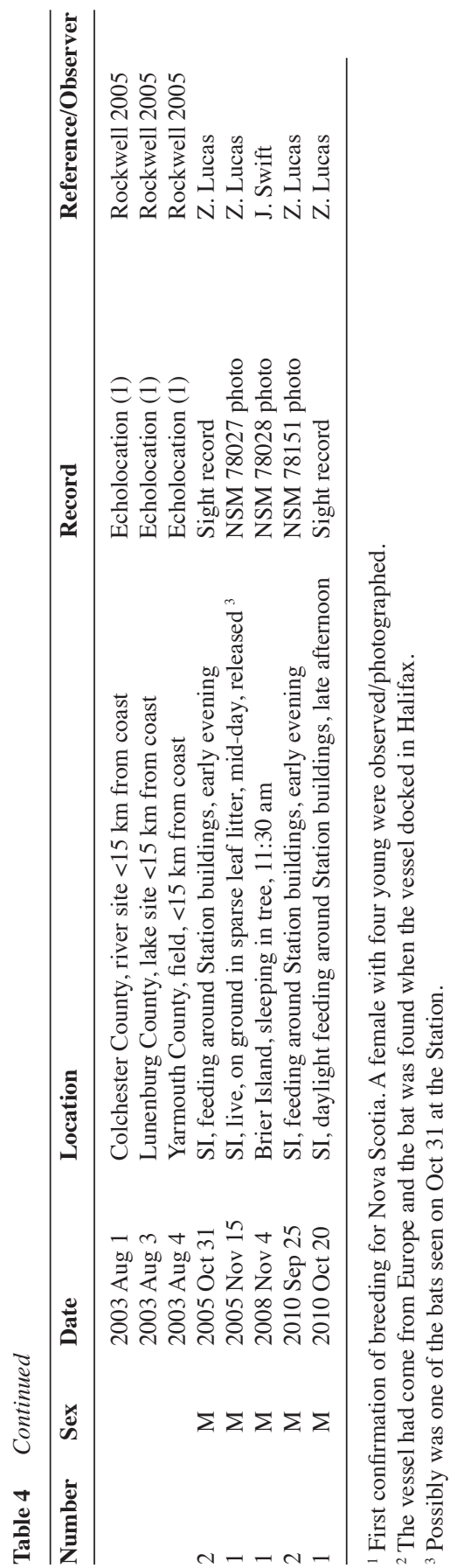


specimens (including 12 at the Nova Scotia Museum of Natural History, Halifax; 2 at Acadia University, Wolfville; 1 at the Royal Ontario Museum, Toronto); 15 by photos; and 15 by echolocation recordings (Broders et al. 2003, Garroway 2004, Rockwell 2005). The remaining 18 are considered to be reliable sight records and/or reports. The earliest are of 2 Hoary Bats, 1 found in Halifax and 1 in Sambro some time before 1864 (Gilpin 1867), but 49\% of records are from 2001 or later, due largely to research in mainland Nova Scotia (e.g., Broders et al. 2003, Garroway 2004, Rockwell 2005), and increased interest on Sable Island. Of 31 previously unpublished records, 11, all since 1999, are from Sable Island.

Month was recorded for 61 records (Table 5), and of these, 47 are from August through November, the autumn migration period for lasiurine bats. Only 9 were in summer (June-July) and 4 in winter (December-February). Of the 47 autumn records, 24 were coastal and 16 offshore, on Sable Island or at sea (Table 5). By species, 7 of 11 Silver-haired Bats, and 13 of 27 Red Bats, were recorded offshore compared with only 2 of 25 Hoary Bats. Of the 40 individual lasiurine bats for which sex was recorded, 31 were male ( 5 of 7 Silver-haired Bats, 7 of 8 Hoary Bats, and 19 of 25 Red Bats).

\section{Sable Island Records}

Useful information on Sable Island occurrences of lasiurine bats is more comprehensive than for other published records for Nova Scotia, and details provide additional insight into their behaviour. On the morning of September 14, 2002, a Silver-haired Bat was found in the Stevenson screen (a wooden box with louvered sides, approximately one meter above the ground, containing thermometers) at the Sable Island Station. The bat appeared to be sunning itself, with head and back exposed, as it rested on a slat in the east-facing (sunny side) of the screen. Later when that side fell into shade, the bat moved into the sunshine on the south side of the screen. The bat was gone by early evening and not seen there again. Occasionally, during the next few weeks, a solitary bat flew around the buildings at dusk but was not identified. On October 8, 2002, in late afternoon, a male Red Bat was seen flying, and apparently feeding, around buildings at the station. This bat was observed for about 30 minutes before it flew out of sight towards the freshwater ponds. 


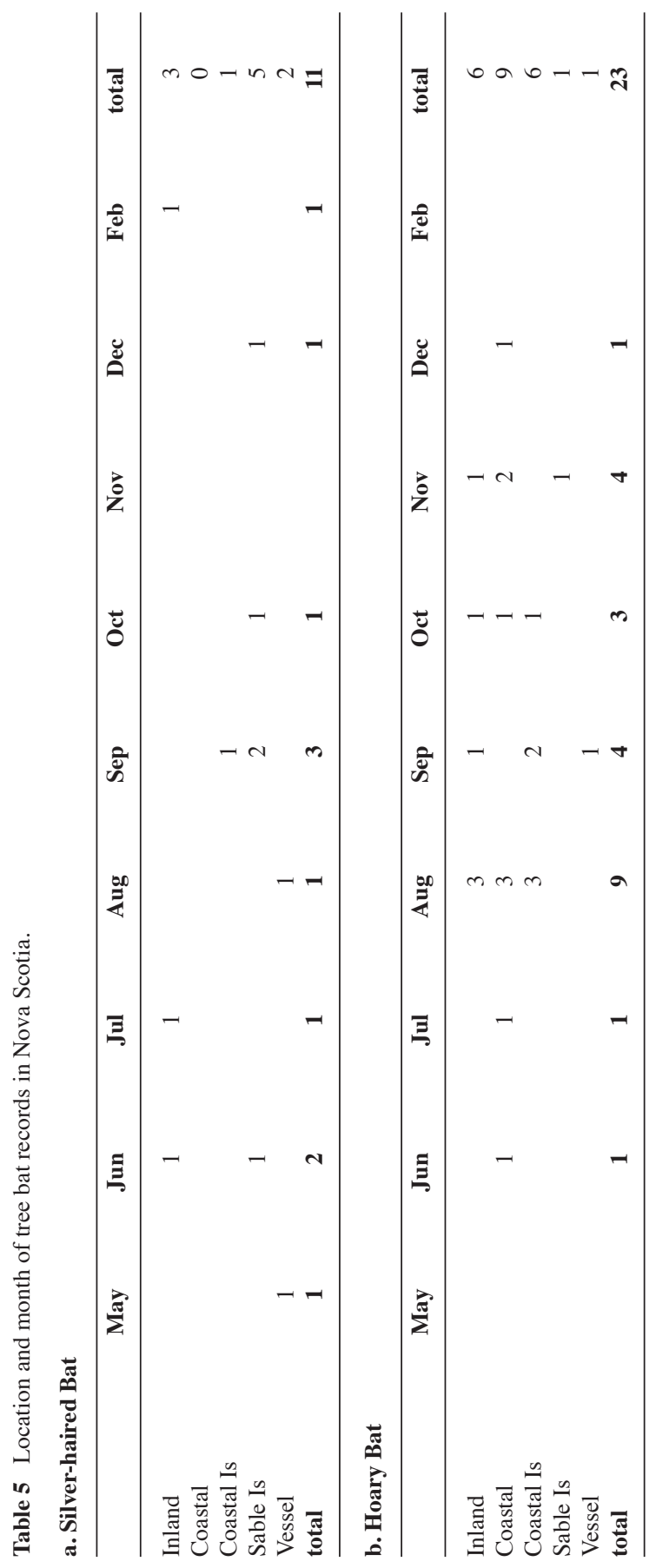




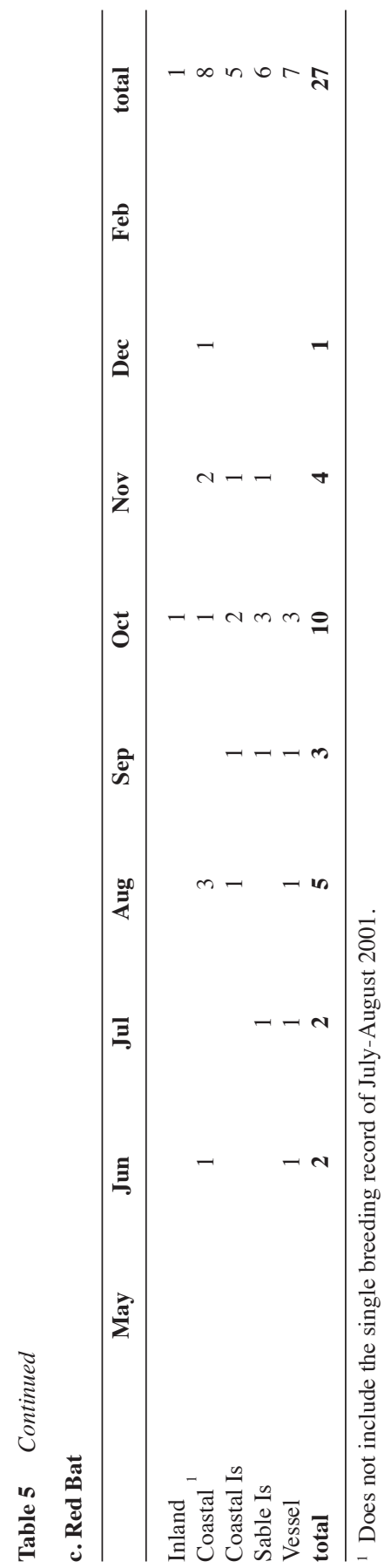


In 2005, all 3 lasiurine species were seen on the island. On the evening of October 25 2005, Hurricane Wilma passed $100 \mathrm{~km}$ south of Sable. During the afternoon and evening, winds gusted to $115 \mathrm{~km} / \mathrm{hr}$ from the southeast, and backing to the east and northeast as the hurricane passed. The first bats were sighted a few days after the hurricane, and 1 to 5 individuals were seen feeding around station buildings every evening until mid-November. On one occasion 2 were identified as male Red Bats. During this same period several grounded bats were recovered. On October 26, 1 wet Silver-haired Bat was found in the Stevenson screen at the station during a night of heavy rain and temperatures of $10.4^{\circ} \mathrm{C}$ to $15.3^{\circ} \mathrm{C}$. The bat was held indoors overnight, and flew off when released the following day. On November 15, a male Red Bat was captured at mid-day when it flew up from leaf litter roughly $2 \mathrm{~km}$ west of the station. It flew off when released after being photographed. The temperature during the previous night was $7.6^{\circ} \mathrm{C}$ to $12.8^{\circ} \mathrm{C}$, and $10.0^{\circ} \mathrm{C}$ when the bat was captured and released. The single Hoary Bat from Sable was found on November 16, wet and torpid on open ground at the side of a cement walkway at the station. Overnight temperatures were $5.7^{\circ} \mathrm{C}$ to $8.4^{\circ} \mathrm{C}$, and $7.1^{\circ} \mathrm{C}$ to $8.4^{\circ} \mathrm{C}$ in the morning when the bat was found. It was taken indoors and within a few hours, presumably after warming up, the bat became active. It was held for three weeks and fed an artificial diet. In captivity the bat was active and capable of flight, and ate regularly. The bat was returned to the mainland where it was weighed (27.6 g), euthanized and tested for rabies (negative). Two wet and grounded adult Silver-haired Bats were found at the Station on December 29. Overnight temperatures were $1.5^{\circ} \mathrm{C}$ to $4.5^{\circ} \mathrm{C}$, and $3.0^{\circ} \mathrm{C}$ to $4.5^{\circ} \mathrm{C}$ during the morning when the bats were found clinging to a cement foundation. They were returned to the mainland and held for four weeks but died in captivity.

During September 2010, 1 to 2 bats were occasionally seen feeding around station buildings after dark. They were identified as Red Bats on September 25 when two males were captured after they hit a window and dropped to the ground. The bats were 'in a clinch' when they hit the glass, and may have been fighting over a prey item. One was held briefly for a photograph, and then released. On October 20, a single male Red Bat was feeding near a station building during late afternoon. 


\section{DISCUSSION}

\section{Normal Coastal Migration}

Although it is well known that lasiurine bats migrate, the timing of these movements in North America is poorly understood (Cryan 2003, Nowak 1994). Cryan (2003) and Findley and Jones (1964) used museum records to examine seasonal movements and distributions of tree bats. Cryan (2003) found that records for each species occur beyond the usual summer range during late summer and early autumn. This expansion may be the result of mating activity or population increase after birth and nursing of young, or it may be associated with exploratory migration (Cryan 2003). Cryan (2003) also found that these 3 species occur along northern coastlines more in autumn than in spring. He suggested that this is associated with coastal navigation augmented by exploratory migration and increase in population size.

Some bats may travel with migratory birds, or use the same migratory routes along the Atlantic seaboard as do many birds (Bleakney 1965, Maunder 1988). Numerous observations, beginning in the late 1800 s, of bats in late summer and autumn flying near, and/or landing on, vessels at sea, flying towards land from offshore, and flying along coastlines, have been recorded for southwest Nova Scotia through to the northeast USA (Allen 1939, Bleakney 1965, Brown 1953, Carter 1950, Griffin 1940, Mackiewicz \& Backus 1956, Miller 1897, Norton 1930, Peterson 1970, Thomas 1921). The number reported ranges from a single bat to hundreds, and in many instances the species were identified as Silver-haired, Hoary, and Red bats. Bleakney (1965) reports information from Brier Island fishermen and suggests that their observations may reflect an autumn migration of bats out of Nova Scotia. Bleakney writes "Digby Neck, Long Island and Brier Island form a long narrow peninsula opposite the coast of Maine. It is known that many Nova Scotia landbirds funnel to the tip of this peninsula in late summer and gather in flocks on Brier Island where they apparently await favourable weather before making the crossing to the United States mainland." Further, Broders et al. (2003) note that if there are any lasiurine bats moving through Nova Scotia in autumn, the northeast-southwest orientation of the province might guide bat migration towards southwest Nova Scotia, resulting in a concentration of bats passing through coastal islands in that region. This is supported by the autumn lasiurine bat records for Nova Scotia reviewed here, mostly from coastal and offshore locations. There may 
be some bias towards a higher number of records in these locations because bats might be more readily sighted in relatively open coastal and offshore areas. Nevertheless, these observations suggest that most of these lasiurine bats are not extralimital. However, some, like the "Wilma" bats on Sable Island, could have been displaced by weather from southern parts of the species' range.

We suggest that the tendency of lasiurine bats to move northwards through the continent during spring migration, and coastward then southward in autumn is likely based on temperature and food availability. During autumn, inland areas cool more rapidly than coastal areas. Thus bats moving towards the coast would be moving into warmer areas where flying insect prey is available later into the season, and also where milder temperatures may reduce energy requirements for normal activities such as arousal, feeding, and seasonal movements.

In Hoary Bat populations there is some segregation of sexes during summer, with males occurring primarily in mountainous regions of western NorthAmerica, and females in eastern areas, although scattered records of male Hoary Bats in more eastern areas during summer may be young-of-the-year (Cryan 2003, Findley \& Jones 1964) and some adult males may also occur in the east. Cryan (2003) suggests that the high proportion of male Red Bat records in northern regions during late autumn and winter indicates that males may not migrate as far south as females. This is consistent with the Nova Scotia observations presented here in which males predominate in all 3 species.

\section{Offshore Occurrences}

Van Gelder and Wingate (1961) note a consistent correlation between the occurrences of waves of bats and waves of birds in Bermuda during the fall migration season, with the largest influxes from September to late November. They suggested that both bats and birds are strays wind-drifted off the American coast while migrating. Hayman (1959) notes that 2 separate Hoary Bats found in Iceland in October may also have been blown off course by a storm (suggested by the occurrence of storm-blown North American birds in Iceland), and that in at least 1 case, this was supported by weather patterns. Maunder (1988) notes that migratory lasiurine bats in Atlantic Canada may simply be fall wanderers, but it seems more likely that at least some of the northeastern records, especially those recorded after mid-September, are the result of "drift migration". McLaren (1981) suggests that "drift migration" is 
responsible for unusual autumn records of birds in eastern Canada and the New England States, and describes "an extraordinary convergence of air masses and wind streamlines" in the Nova Scotia region during both spring and autumn landbird migrations. He also notes that during early autumn winds from the mid-western to southeastern USA, converge on Nova Scotia and continue on out to sea. McLaren et al. (2006) examined the occurrence of avian transatlantic vagrants from eastern North America and the meteorological systems associated with species composition and distribution. Their analyses supported earlier suggestions that many vagrant North American landbirds occurring in Britain and Ireland in autumn are likely displaced downwind across the North Atlantic after becoming entrained in strong southwest winds in warm sectors ahead of cold fronts along the eastern seaboard of North America.

Migratory lasiurine bats found in offshore areas of Nova Scotia may be individuals caught up in the same weather patterns. Of the 47 lasiurine bats recorded in Nova Scotia during August through November, 24 occurred along the mainland coast and on coastal islands, and 16 occurred on vessels and at Sable Island. The latter may have been individuals displaced beyond what is likely a normal coastal migration route along the Atlantic coast of Nova Scotia and northeastern USA.

Since the 1970s, there have been occasional sightings of bats on Sable Island. The first confirmed lasiurine bat record for the island was a Red Bat from 1976. Subsequently several live individuals were dislodged from piles of lumber during spring maintenance activities, and some were seen feeding around the Station buildings during late afternoon or dusk in autumn, however most were not identified (e.g., 4 individuals feeding near the Station after dusk between October 30 and November 8,2006). No additional records were kept until autumn 2002 when a Red Bat and a Silver-haired Bat were photographed at the Sable Station.

During autumn 2005, there was an increase in bat sightings following Hurricane Wilma. This coincided with the appearance of large numbers of rare or extraseasonal birds in the wake of the hurricane that generated a great deal of interest in Atlantic Canada (McLaren $\&$ Mills 2006). Species sighted on the mainland and on Sable Island included Sterna caspia (Caspian Tern), S. maxima (Royal Tern), S. sandvicensis (Sandwich Tern) and S. forsteri (Forster's Tern), and Coccyzus americanus (Yellow-billed Cuckoo). On Sable, as in mainland 
Nova Scotia and Cape Breton, extralimital or extraseasonal sightings of birds are sometimes attributed to the high winds of gales, tropical storms and hurricanes, although McLaren (1981) notes that the role of weather in displacing landbird migrants is generally through geostrophic wind patterns rather than through storms. It is possible that the weather systems that brought the many southern and/or migratory birds to Sable Island in autumn 2005 also brought the lasiurine bats. Thus while lasiurine bats found along the coast of mainland Nova Scotia and on coastal islands would be within a normal migratory corridor for these species, bats on Sable Island, and sighted well offshore flying or resting on vessels, are likely animals displaced by weather, including strong offshore winds. This may be an important factor in the much lower occurrence of Hoary Bats found offshore. Hoary Bats are more than twice the size of Silver-haired Bats and Red Bats, and thus probably stronger fliers, less prone to being blown offshore, or more likely get back on course after being displaced. However, 6 of the 12 individual Silver-haired Bats were found on Sable Island. They are the smallest of the lasiurine bat species, and may be more vulnerable displacement by strong winds.

\section{CONCLUSIONS}

Although no comprehensive surveys for lasiurine bats have been conducted in Nova Scotia, extensive echolocation surveys have suggested that there are no significant populations of these species in the Province. While the records considered here are largely from incidental observations, the seasonality of these records suggests that most occurrences of these species in Nova Scotia are likely not extralimital. Instead they may be part of normal migratory movements toward coastal areas and then southward to overwintering areas. The lasiurine bats involved in these movements may comprise animals migrating coastward from other regions in eastern Canada and/or individuals from small breeding populations in Nova Scotia.

Acknowledgements We thank Gerry Forbes and staff of the Sable Island Station, Meteorological Service of Canada; Judith Eger, Royal Ontario Museum; Fred Scott,Acadia University; Sherman Boates, Nova Scotia Natural Resources; the many people who contributed sightings details; and ExxonMobil Canada, Ltd. Hugh Broders, Saint Mary's 
University, and Ian McLaren reviewed an early draft of the manuscript and provided many helpful comments and insights.

\section{LITERATURE CITED}

Allen, G.M. (1939) Bats. Cambridge: Harvard University Press.

Banfield, A.W.F. (1974) Mammals of Canada. University of Toronto Press, Toronto, Canada.

Bleakney, J.S. (1965) Notes on the migratory tree bats of Nova Scotia. Canadian Field-Naturalist 79:154-155.

Broders, H.G., Quinn, G.M. \& Forbes, G.J. (2003) Species status, and the spatial and temporal patterns of activity of bats in southwest Nova Scotia, Canada. Northeastern Naturalist 10:383-398.

Brown, N.R. (1953) An addition to the list of mammals of Nova Scotia: the Eastern Red Bat. Canadian Field-Naturalist 67:139.

Carter,T.D.(1950) On the migration of the red bat, Lasiurus borealis borealis . Journal of Mammalogy 31:349-350.

Catling, P.M., Freedman, B. \& Lucas, Z. (1984) The vegetation and phytogeography of Sable Island, Nova Scotia. Proceedings of the Nova Scotian Institute of Science 34:181-247.

Cryan, P.M. (2003) Seasonal distribution of migratory tree bats (Lasiurus and Lasionycteris) in North America. Journal of Mammalogy 84:579-593.

Fenton, M.B.(1983) Just Bats. University of Toronto Press, Toronto, Canada.

Findley, J.S. \& Jones, C. (1964) Seasonal distribution of the hoary bat. Journal of Mammalogy 45:461-470.

Garroway, C.J.(2004) Inter- and intraspecific temporal variation in the activity of bats at two Nova Scotia hibernacula. Thesis, Saint Mary's University, Halifax, Nova Scotia.

Gilpin, J.B. (1867) On the mammalia of Nova Scotia. Transactions of the Nova-Scotian Institute of Natural Science 1:8-15.

Griffin, D.R. (1940) Migrations of New England bats. Bulletin: Museum of Comparative Zoölogy 76:217-246.

Hall, E.R. (1981) The Mammals of North America. Vol.1. John Wiley \& Sons, New York.

Hayman, R.W. (1959) American bats reported in Iceland. Journal of Mammalogy 40:245-246.

Hitchcock, H.B. (1943) Hoary bat, Lasiurus cinereus, at Southhampton Island, N.W.T. Canadian Field-Naturalist 57:86.

Mackiewicz, J. \& Backus, R.H. (1956) Oceanic records of Lasionycteris noctivagans and Lasiurus borealis. Journal of Mammalogy 37:442-443.

Maunder,J.E. (1988) First Newfoundland record of the Hoary Bat, Lasiurus cinereus, with a discussion of other records of migratory tree bats in Atlantic Canada. Canadian Field-Naturalist 102:726-728.

McLaren, I.A. (1981) The incidence of vagrant landbirds on Nova Scotian Islands. Auk 98:243-257. 
McLaren, I.A.\& Mills, E. (2006) Weather and birds: a Review of a remarkable season. Nova Scotia Birds 48:8-9.

McLaren, I.A., Lees, A.C., Field, C. \& Collins, K.J. (2006) Origins and characteristics of Nearctic landbirds in Britain and Ireland in autumn: a statistical analysis. Ibis 148:707-726.

Miller, G.S. (1897) Migration of bats on Cape Cod, Massachusetts. Science 5:541-543.

Moseley, M.(2007a)Acadian biospeleology: Composition and ecology of cave fauna of Nova Scotia and southern New Brunswick, Canada.International Journal of Speleology 36:1-21.

Moseley, M. (2007b) Records of bats (Chiroptera) at caves and mines in Nova Scotia.Nova Scotia Museum. Curatorial Report; no.9, Halifax, Nova Scotia.

Norton, A.H. (1930) A red bat at sea. Journal of Mammalogy 11:225-226.

Nowak, R.M.(1994) Walker's Bats of the World. The Johns Hopkins University Press, Baltimore and London.

Peterson, R.L. (1970) Another red bat, Lasiurus borealis, taken aboard ship off the coast of Nova Scotia. Canadian Field Naturalist 84:401.

Peterson, R.L. (1966) The Mammals of Eastern Canada. Toronto, Oxford University Press.

Rockwell, L. (2005) Summer distribution of bat species on mainland Nova Scotia. Unpublished thesis, Saint Mary's University, Halifax, Nova Scotia.

Scott, F.W. \& Hebda AJ (2004) Annotated list of the mammals of Nova Scotia. Proceedings of the Nova Scotian Institute of Science 42:189-208.

Thomas, O. 1921. Bats on migration. Journal of Mammalogy 2:167.

Tuttle, M.D. (1995) The Little-known World of Hoary Bats. Bats 13:3-6.

Van Gelder RG, \& Wingate, DB (1961) The taxonomy and status of bats in Bermuda. American Museum Novitates 2029:1-9.

Van Zyll de Jong, C.G. (1985) Handbook of Canadian Mammals, vol. 2: Bats. National Museum of Natural Sciences, National Museums of Canada, Ottawa, Canada, pp. 128-145. 
